\title{
Dynamic Capabilities and Mediating Effects of Innovation on the Competitive Advantage and Firm's Performance: the Moderating Role of Organizational Learning Capability
}

\author{
Jorge Ferreira ${ }^{1} \cdot$ Sofia Cardim ${ }^{2} \cdot$ Arnaldo Coelho $^{3}$
}

Received: 26 February 2018 / Accepted: 13 April 2020/Published online: 04 June 2020

(C) Springer Science+Business Media, LLC, part of Springer Nature 2020

\begin{abstract}
The objective of this paper is to investigate the impact of exploration and exploitation capabilities on competitive advantage (hereafter CA) and performance, considering the mediating role of innovation capabilities (hereafter ICs) and the moderating role of organizational learning capability (hereafter OLC) on the proposed relationships. This investigation proposes a theoretical model tested using structural equation modelling (SEM), and a multi-group analysis is performed to understand the moderating role of organizational learning capability. A 90-item questionnaire exploring the relationships between dynamic capabilities (hereafter DCs) and innovation was developed, and a total of 387 valid questionnaires were collected from a sample of Portuguese's smalland medium-sized enterprises (SMEs), a case of a transition economy. Therefore, this study contributes to the understanding of the direct and indirect impact of exploration and exploitation on $\mathrm{CA}$ variables, the mediating role of IC on CA and performance and the moderating effect of OLC in a transition economy.
\end{abstract}

Keywords Dynamic capabilities · Innovation capabilities · Organizational learning capability $\cdot$ Performance

Jorge Ferreira

jorge.ferreira065@gmail.com

Sofia Cardim

sofiacardim@ipb.pt

Arnaldo Coelho

coelho1963@hotmail.com

1 Faculty of Economics at University of Coimbra, Coimbra, Portugal

2 Polytechnic Institute of Bragança, Bragança, Portugal

3 Faculty of Economics at University of Coimbra, Coimbra, Portugal 


\section{Introduction}

This paper aims to examine the relationship between DCs, exploration and exploitation and firm CA. In addressing this aim, ICs are a mediator in the relationship between DCs and firm CA and OLC.

In the scientific literature, researchers (Eisenhardt and Martin 2000; Porter 1990; Teece et al. 1997; Zollo and Winter 2002) recognize DCs to be a key factor in firm competitiveness through sensing, seizing and reconfiguring (Li et al. 2008; Ohr and Mattes 2013; O'Reilly and Tushman 2008; Raisch et al. 2009; Teece et al. 1997). It has been confirmed that DCs have direct and indirect impact on firm CA. A significant number of researchers (Eisenhardt and Martin 2000; Helfat 1997; Li and Liu 2014; Teece 2007; Teece et al. 1997) analysed DCs' impact on firm CA. Each of these studies, though using different variables, indicates that the relation between DCs and firm CA can be direct and indirect. Accordingly, it is necessary to identify variables that can have a mediating effect on this relation. Also, previous studies (He and Wong 2004; Jansen et al. 2006) have confirmed innovations to be a source of CA. However, there is still no empirical evidence of organizational ambidexterity's impact on firm CA in terms of exploitation and exploration.

March (1991) has noted, however, that these two activities compete for the same pool of scarce resources which has often resulted in firms favouring one at the expense of the other. Consequently, the challenge facing firms and researchers is to discover how to leverage a firm's capabilities in ways that will enable it to successfully engage in both types of activities simultaneously. Some researchers suggest that it is possible to balance the pursuit of exploitation and exploration by creating a behavioural context that is characterized by the interaction of stretch, discipline, support and trust (Gibson and Birkinshaw 2004), but beyond that importance, however, there is a marked lack of understanding the specific capabilities that are required to simultaneously achieve radical and incremental innovation (Adler et al. 1999; Simsek et al. 2009). Some researchers have proposed that practices facilitating learning and knowledge transfer are particularly important to innovation (Kogut and Zander 1992; Teece and Pisano 1994). Some of the practices that researchers have studied include how organizations collaborate with other organizations (Lichtenthaler 2009; Mishra and Shah 2009), how organizations promote learning (Tsai 2002) and how an organization's culture facilitates knowledge transfer and learning (Leonard-Barton 1992).

The body of literature on the moderating relation between OLC (in particular, the commitment to learning dimension) and innovation is growing and suggests that organizational learning would enhance the innovative capacity of an organization and also advocates that firms can only innovate if they develop an efficient learning of their resources, competencies and capabilities (Alegre and Chiva 2008; Akgün et al. 2007; Argyris and Schon 1978; Calantone et al. 2002; Chipika and Wilson 2006; Helfat and Raubitschek 2000; Sinkula et al. 1997; Stata and Almond 1989). These innovative activities may be bounded by the firm's existing routines, processes and experiences, which are called knowledge inertia (Li et al. 2016; Xie et al. 2016). Thus, innovation may increase when organizations overcome knowledge inertia through organizational learning, culture and knowledge management.

Previous studies in this area have mainly focused on firms operating in developed markets, and few focuses about what DCs are, or their relationship with performance in 
transition economies. Thus, the study uses Portugal as a testing ground for the universality of the generated theory as an example of a transition economy: Portugal is the second largest country in the European Union in terms of the number of smalland medium-sized enterprises (SMEs) per 100 inhabitants, just behind the Czech Republic, and ranks 14th in the category of the most innovative countries in the European Union.

This investigation presents two major contributions: first, investigating the chain of effects between dynamic capabilities (exploration and exploitation capabilities) and competitiveness and performance, and second, this investigation uses the combined effects of innovation on competitive advantage and performance, as a result of the impulse given by exploration and exploitation. Finally, it introduces the contextual effects of organizational learning capability (commitment to learning) in a sample of companies from a transition economy, investigating how it might affect the proposed relationships.

To fill theses gaps, in this paper we investigate the impact direct and indirect impact of dynamic capabilities (hereafter DCs) (exploitation and exploration capabilities) on $\mathrm{CA}$ and performance, considering the mediating role of innovation capabilities (hereafter ICs). The moderating role of OLC was introduced to establish a specific environment which could boost or inhibit the proposed relationships. This investigation is based on a sample of 387 Portuguese SMES, operating in a transition economy.

\section{Background and Research Hypotheses}

\section{Dynamic Capability Approach}

The DCs' literature has its roots in the Resource-Based View of the firm (RBV), going all the way back to the works of Penrose in 1959. However, other streams of literature have also influenced the discussion, specifically the evolutionary theory of economic change (Nelson and Winter 1982), Schumpeter's views on creative destruction, the behavioural aspects of the firm (Cyert and March 1963) and Williamson's (1975) views on markets and hierarchies (Ambrosini and Bowman 2009; Teece 2007). The conceptual discussion is, therefore, very rich. Many authors perceive DCs as higher-order capabilities that influence the development of operational capabilities (Cepeda and Vera 2007; Collis 1994; Winter 2003). They are often combinations of simpler capabilities and the routines related to them (Eisenhardt and Martin 2000). Thus, DCs are defined at this juncture as the capacity of the organization to purposefully create, extend or modify its resource and capability bases to address changes in its environment (Eisenhardt and Martin 2000; Helfat 2007; Teece and Pisano 1994; Winter 2003). DCs are described as processes (Ambrosini and Bowman 2009) or as comprising processes (Teece et al. 1997; Verona and Ravasi 2003). Thus, they are dynamic by implication as they operate in time and develop over time.

Although scarce, there is some conceptual discussion related to these constituent processes: they are assumed to include both organizational and managerial processes aimed at identifying needs or opportunities for change and at accomplishing that change (Helfat 2007). This remains an on-going conceptual debate. To enhance conceptual coherence and clarity, Zahra et al. (2006) suggest separating DCs from 
their antecedents and outcomes. Considering antecedents as inputs and outcomes as outputs is a good starting point from which to analyse the accumulated knowledge. Teece (2007) offers a focal contribution regarding the antecedents of DCs in writing about the micro-foundations that are contributory factors. To provide analytical clarity, he distinguishes between the micro-foundations for each of the three dimensions: sensing, seizing and reconfiguration. Finally, in terms of outcomes, there is agreement that DCs are linked to the CA of the firm or to its performance (Eisenhardt and Martin 2000; Helfat and Peteraf 2003; Winter 2003), although there is some debate about the mechanisms of this linkage (Ambrosini and Bowman 2009). Early on it was suggested to be direct (e.g. Teece and Pisano 1994), but more recently it has been described as indirect, meaning that DCs influence performance through the unique resource and capability configurations they develop (Helfat and Peteraf 2003; e.g. Zollo and Winter 2002).

Several authors conceptualize DCs as exploitation and exploration (Vahlne and Jonsson 2017). These two dimensions correspond to different DCs: exploration is disruptive and is about the development of new knowledge; exploitation is about exploring actual knowledge based on efficiency, certainty and improvement of known solutions (O'Reilly and Tushman 2008; p. 189).

DCs consequently comprise various processes, arguably influenced by many different factors called antecedents.

\section{The Exploration and Exploitation as Dynamic Capabilities}

To examine the findings on ambidexterity in the research stream of strategic management, Raisch and Birkinshaw (2008) refer to the internal ecology model of strategy developed by Burgelman (1991, 2002). According to this model (see Fig. 1), there are two processes which can be related to either exploration or exploitation. The first process is the induced strategic procedure which focuses on the use of already existing knowledge and can, therefore, be related to exploitation. The second process is the autonomous strategic procedure including the creation of new skills and competencies which can be related to exploration.

Like many other researcher's findings, Burgelman (1991) argues that organizational success can be achieved through a balance between the two processes of exploration

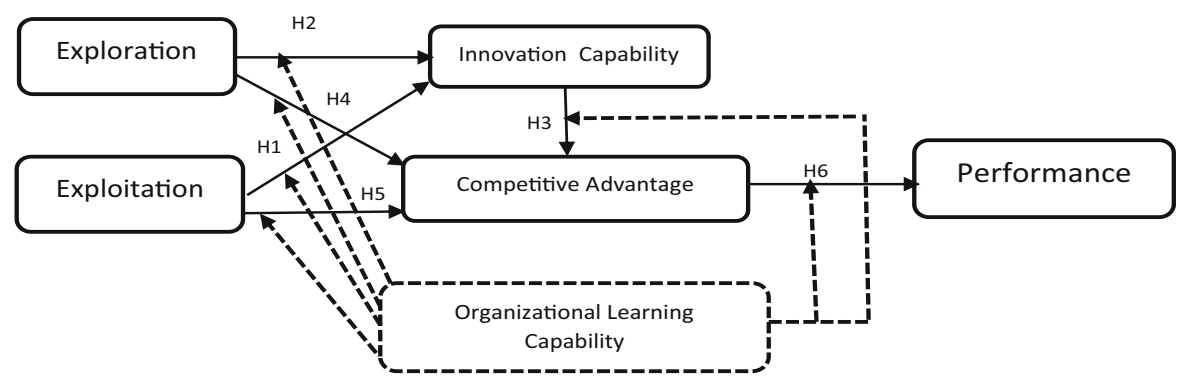

--ー-- Moderating Effect

Source: Self elaboration

Fig. 1 Conceptual Model 
and exploitation. DCs of a firm are closely linked to the concept of ambidexterity and have its roots in the strategic management domain. Therefore, the topic of DCs and its connection with ambidexterity will be briefly addressed in this section. Various scholars (e.g. He and Wong 2004; O'Reilly and Tushman 2008) refer to the notion of DCs when trying to explain the balance between exploration and exploitation. The linkage of DCs and ambidexterity has also been considered by other researchers which discuss meta-capabilities (Gibson and Birkinshaw 2004) or meta-routines (Adler et al. 1999) in this regard. Teece et al. (1997) define DCs as "the firm's ability to integrate, build, and reconfigure internal and external competences to address rapidly changing environments" (p. 516). To conclude, DCs enable a firm to exploit existing competencies and to simultaneously explore new competencies as well as to reconfigure organizational resources to seize existing and emerging opportunities (O'Reilly and Tushman 2008). Ambidexterity is thus a DCs as the simultaneous pursuit and reconfiguration of exploration and exploitation processes allow firms to adapt to changing environments.

\section{Innovation Capabilities}

ICs are defined as a set of processes that are related to new product development and improving product quality (O'Cass and Sok 2012) and which play a key role in organizational development and growth (Camisón and Villar-López 2014). Also, Akman and Yilmaz (2008) define IC as an important factor that facilitates an innovative organizational culture, the characteristics of internal promoting activities and the capabilities of understanding and responding appropriately to the external environment. A firm's IC can also be described as its ability to develop innovations continuously as a response to a changing environment (Saunila et al. 2014).

\section{The Impact of Exploitation and Exploration on Innovation Capability}

Exploration and exploitation are perceived as a factor to increase organizational performance and innovation (Levinthal and March 1993; Katila and Ahuja 2002) and realized as variables that alleged have a positive influence on IC (Cao et al. 2009; Gibson and Birkinshaw 2004; Marín-Idárraga et al. 2016). Likewise, exploitative innovation enhances and improves available knowledge and skills, and, in contrast, exploration discovers new ideas (March 1991).

Consequently, the following hypotheses are proposed:

H1: Exploitation positively impacts on innovation capability.

$\mathrm{H} 2$ : Exploration positively impacts on innovation capability.

\section{The Impact of Innovation Capabilities on Competitive Advantage}

Some companies are more successful than others when dealing with dynamic environments, operating with lower costs and providing superior value to their customers. According to Peteraf and Barney (2003), a firm has a CA when she operates with greater success than its competitors, leading to a superior performance. CA and performance are related concepts, but different in their foundations, therefore, competitiveness is supposed to contribute to a firm performance. 
According to Tidd (2006), innovation contributes to achieving a CA in several different aspects. The most important characteristics of innovation include the following: a strong relationship between market performance and new products; the ability to substitute outdated products (shortening product lifecycles); and innovation in processes that lead to shortening production time and speed up new product development in comparison to competitors. Martín-de Castro et al. (2013) state that developing successful technological innovations is essential for creating and sustaining an organization's CA. According to Zemplinerová (2010), the expenditures on research, development and introduction of innovations are the determining characteristics for gaining a dominant part of the market. Autant-Bernard et al. (2013) in their survey also show the importance of the role of the regional innovation, and they argue that organization must have original strategies and support the knowledge flows from and to organization (Hurley and Hult 1998; Lee et al. 2011).

IC is critical to any firm wishing to secure a dominant position and achieve higher profits (Cheng and Huizingh 2010). It has a considerable impact on corporate performance by producing an improved market position that conveys CA and superior performance (Kafetzopoulos and Psomas 2015). McAdam and Keogh (2004) found that a firm's inclination to innovate was of vital importance in the competitive environment for it to obtain a higher CA. Recently, Cheng and Huizingh (2010) have supported the view that innovation is critical to a firm wishing to obtain a dominant position and achieve higher profits. Therefore, IC can affect CA and performance (Suliyanto 2011; Suharyono et al. 2014). Consequently, the following hypothesis is proposed:

H3: Innovation capability has a positive impact on competitive advantage.

\section{The Impact of Exploration and Exploitation on Competitive Advantage}

Firms that are involved in these processes of exploration and exploitation generate a CA by making revolutionary and evolutionary changes (Tushman and O'Reilly III 1996; Benner and Tushman 2003) or focusing on adaptability and alignment (Gibson and Birkinshaw 2004; Preda 2014). Tushman and O'Reilly III (1996) describe ambidextrous organizations as having the ability to develop new products and services for emerging markets and to compete in mature markets simultaneously. Scholars of strategic management (Eisenhardt and Martin 2000; Teece, et al.1997) highlight that a firm's capability to reconfigure the dynamic processes of exploitation and exploration, also known as "dynamic capability", is the key source of its sustainable CA. They also suggest that firms that successfully reconfigure their competence base to match emerging market opportunities faster than their rivals are more likely to achieve superior performance. Consequently, the following hypothesis is proposed:

H4: Exploitation has a positive impact on competitive advantage.

H5: Exploration has a positive impact on competitive advantage.

\section{The Impact of Competitive Advantage on Performance}

Firm performance is usually conceptualized based on 4 dimensions (Narver and Slater 1990, 2002; Akman and Yilmaz 2008): innovative performance, production performance, market performance and financial performance. CA and firm 
performance are two different constructs with an apparently complex relationship (Ma 2000). That said, there is a definite and significant relationship between them (Gimenez and Ventura 2003; Wiklund and Shepherd 2003). This significant relationship between CA and the performance of organizations has been verified when sales-based performance was measured by the level of sales revenue, profitability, return on investments, productivity, product added value, market share and product growth (Rose et al. 2010).

In this sense, a number of prior studies have discussed the relationships between CA and organizational performance in the field of strategic management (Yang and Huang 2009). According to Hult and Ketchen (2001, pp. 902), a CA supposes that the firm is a position "valuable, rare and difficult to acquire", which is a resource that can lead to a superior performance. According to Kuo et al. (2017), CA has a significant effect on organizational performance because employee-driven performance is the key which can increase both CA and organizational performance. Consequently, the following hypothesis is proposed:

H6: Competitive advantage has a positive impact on performance.

\section{The Moderating Role of Organizational Learning Capability}

OLC is fundamental to a firm's innovation. It refers to the ability of an organization to implement the proper management practices, structure, procedures and policies that facilitate and foster learning (Goh 2003). This ability enables the process of organizational learning. Organizations create such capability by putting in place factors that facilitate the organizational learning process or allow an organization to learn. OLC should be able to create, acquire, transfer and integrate new knowledge as well as modify existing behaviour to reflect new knowledge with a view to improve performance (Jerez-Gomez et al. 2005). Learning is an important factor in an organization because it enables the creation and expansion of a sustainable CA. Indeed, learning can serve as a means of creating and developing wide range of organizational capabilities, thus driving firms to continuous improvement rather than focusing on specific types of knowledge (Goh 2003; Schendel 1996). Recently, Alegre and Chiva (2008) found that OLC positively influences product innovation performance. Information systems (IS) literature has pointed out the criticality of OLC for organizational innovation (Fang et al. 2011; Hult et al. 2004; Robey et al. 2002).

Furthermore, the relationship between exploitation, creativity, innovation and performance at both the organizational and individual level is still ambiguous. Some studies find positive relationships between exploitation and outcome dependent variables (Hahn et al. 2015) such as strategic entrepreneurship, strategic resource management and CA (Kyrgidou and Petridou 2011) and open systems performance (Hernández-Espallardo et al. 2011). However, other studies do not find relationships between exploitation and performance in terms of profit (Sirén et al. 2012), between exploitation and new product differentiation (Lisboa et al. 2011) and between exploitation-based innovation and rational goal performance (Hernández-Espallardo et al. 2011). Despite these contradictory results for exploitative learning strategy and the outcome variables, few studies address the effect of exploitation on SMEs' creativity and innovativeness. 
On the other hand, exploration in organizational learning refers to "search, variation, risk taking, experimentation, play, flexibility, and discovery" (March 1991, p. 71) and extends to using knowledge and technologies from the external environment. The new knowledge may be internal or very novel external information. Exploration can be a valid choice, though this choice can take firms away from the original goals (Vanhaverbeke et al. 2004), while they use external knowledge to complement internal knowledge and technology or impose high costs from experimentation, incompetence or undeveloped ideas. Exploration is a long-term goal to achieve after practicing an exploitation to enter new markets and create new ideas, products and services. Researchers currently use the terms exploration and exploitation to find a balance between them (Schildt et al. 2005; Vanhaverbeke et al. 2004) and express the challenges the firms currently face (Haanaes 2016). The researcher must determine whether learning strategies are bidirectional or unidirectional given that this relationship is still unknown. For instance, Hahn et al. (2015) find a positive relationship between exploitation and exploration, but other researchers believe that exploitative learning occurs during explorative learning (Atuahene-Gima and Murray 2007; Schildt et al. 2005) and exploration creates opportunities that firms can later exploit (Lavie et al. 2010). Organizational learning is continuous, and this study posits that exploration can trigger exploitation by adding new knowledge to the current knowledge pool.

\section{Methodology}

\section{Sample and Data Collection}

To test the proposed investigation model and the research hypotheses, the data was collected through a structured questionnaire (see Fig. 1). Using information obtained from SME business associations, a total of 387 questionnaires were distributed to a convenience sample of Portuguese SMEs during the first semester of 2017, and a key informant in each company was contacted with a request to complete the questionnaire, delivered face to face, using a snowball approach. Each respondent was asked to identify and help contact between 3 and 5 new respondents, until we get the final sample. Of these, $28 \%$ were from companies with less than 20 employees, $42 \%$ had between 21 and 50 employees, $8 \%$ had between 51 and 100 employees and 22\% between 101 and 200 employees. Regarding to legal constitution, $43 \%$ were share companies, $42 \%$ private limited companies and $15 \%$ single shareholder companies. In terms of lifespan, $25 \%$ were less than 10 years old, $65 \%$ between 10 and 20 years, $7 \%$ between 21 and 50 years and $3 \%$ more than 51 years. The respondents were scattered throughout the country with no sector being specially represented.

\section{Measures}

To operationalize the variables, a literature review on the subject matter was previously conducted and selected the instruments and adapted the scales used in pre-existing studies, changing and adapting the vocabulary so that the questions 
were more perceptible to Portuguese respondents. The measures are presented as an (see. Appendix).

\section{Innovation Capability (IC)}

The survey instrument asked respondents to indicate their perceptions regarding IC based on the 4-item scale from Merrilees et al. (2011). Items like "Better at developing new ideas to help customers" were used.

\section{Dynamic Capabilities (DCs): Exploration and Exploitation}

DCs - exploration and exploitation-were measured using two dimensions, with five items each, competence exploration and competence exploitation, suggested by Atuahene-Gima (2005). Items like "Acquired manufacturing technologies and skills entirely new to the firm" were used as well as "Upgraded current knowledge and skills for familiar products and technologies".

\section{Competitive Advantage (CA)}

CA was already measured by Thatte et al. 2009, based on the scales from Koufteros et al. (1997), considering cost, quality, dependability and speed of delivery as some of the critical competitive priorities. Items like "offer prices as low as or lower than our competitors" were used.

\section{Performance}

Performance was measured based on Morgan and Strong's (2003) research work and then used by Thatte (2007). This scale typically captures "return on ..." or "re-investment" type measures that express profit and cash flow as well as customer satisfaction and the growth on sales and on market share. The scale is composed of 7 items.

\section{Organizational Learning Capability (OLC)}

As discussed in the literature review, the measures used in this investigation are based on Tohidi et al. (2012) using the dimension managerial commitment to learning, once it is the one who better expresses the organizational strategy. The other 5 OLC dimensions express a more operative approach of this concept. The dimension managerial commitment expresses the belief and support that managers can bring to a learning culture development (Tohidi et al. 2012). The final measure used consisted of 6 items, related to learning commitment, in which managers were asked to assess their firm's behaviour during the past years. In this investigation, it was considered a cut-off point on commitment based on this ability to concentrate on OLC. Consequently, the sample was divided into two distinct groups: higher organizational learning culture for companies computing above average on commitment and lower organizational learning culture for companies computing below the average on at least one of commitment. 


\section{The Model}

All the items were measured on a 7-point Likert scale $(1=$ strongly disagree to $7=$ strongly agree). Confirmatory factor analysis was used to assess the psychometric properties of the scales and the measurement model adjustment, using Amos Version 21.0. The final model shows a good adjustment (IFI $=0.920 ;$ TLI $=$ 0.911; CFI = 0.920; RMSEA = 0.071; CMIN/DF = 2.950) (see Fig. 1).

Composite reliability (CR) and the average variance extracted (AVE) were computed. All the scales showed values above 0.8 on $\mathrm{CR}$ and above 0.7 on AVE (see Table 1) which are in line with the recommendations (Hair Jr. et al. 2006). Discriminant validity is evidenced by the fact that all correlations between the constructs are significantly smaller than 1 and the squared correlations calculated for each pair of constructs is always smaller than the variance extracted for correspondent constructs (Shiu et al. 2011), thereby confirming the discriminant validity.

\section{Common Method Bias}

The common method bias refers to the variance that depends on the measurement method rather than the metrics used, namely, like in our investigation where information was collected from a single informant.

Based on the suggestions by Podsakoff and Organ (1986), a Harman's single factor test and a common latent factor (CLF) analysis were performed to capture the common variance among all observed variables in the model. The Harman's test showed that any factor could explain more than $23 \%$ of the variance and there were 11 factors with eigenvalues greater than 1 , explaining $73 \%$ of the total variance. A confirmatory factor analysis was conducted restricting all items of the model to load on a common single factor (Podsakoff and MacKenzie 2003). The resulting adjustment indices show that the model did not provide a good adjustment for the data: $\mathrm{CMIN} / \mathrm{DF}=2.02 ; \mathrm{IFI}=0.68 ; \mathrm{TLI}=0.673 ; \mathrm{CFI}=0.680$; RMSEA $=0.48$.

Table 1 Square correlations, Cronbach's alpha, composite reliability and variance extracted

\begin{tabular}{llllllll}
\hline Construct & X1 & X2 & X3 & X4 & X5 & CR & AVE \\
\hline Exploitation & 0.94 & & & & & 0.89 & 0.72 \\
Exploration & 0.63 & 0.89 & & & 0.92 & 0.78 \\
Innovation capability & 0.42 & 0.43 & 0.88 & & & 0.91 & 0.76 \\
Competitive advantage & 0.55 & 0.37 & 0.63 & 0.90 & & 0.91 & 0.76 \\
Performance & 0.37 & 0.21 & 0.55 & 0.33 & 0.94 & 0.93 & 0.76 \\
\hline
\end{tabular}

Diagonal in bold, Cronbach's Alpha; $C R$ composite reliability, AVE average variance extracted

Source: Self elaboration (2014) 


\section{Results and Discussion}

Amos 21.0 was used to perform CFA and SEM to test the proposed hypotheses. The final model shows a good adjustment (IFI $=0.920 ;$ TLI $=0.911$; CFI $=0.920$; RMSEA $=0.071 ; \mathrm{CMIN} / \mathrm{DF}=2.950)$. A multi-group analysis was performed to test the moderation effects of OLC, considering two groups: the low OLC group, with 189 respondents; and the high OLC group with 198 respondents. A chi-squared test was performed to compare the two groups, and the results show a significant difference between them. The differences between the unconstrained model (chi-squared = 1394,$906 ; \mathrm{DF}=630$ ) and the fully constrained model (chi-squared $=1443,310 ; \mathrm{DF}=$ 658) show that the models are different (chi-squared $=49 ; \mathrm{DF}=28 ; P \leq 0.05 ; \mathrm{CV}=$ 50,993 ) and that the moderation effects are significant. Table 2 shows the results of the estimation of the structural model. The adjustment of the model is good (Anderson and Gerbing 1988).

\section{Exploitation and Exploration and Innovation Capability}

H1 is supported, as exploitation has a positive impact on innovation capability ( $r=$ $0,348 ; P=* * *)$, and $\mathrm{H} 2$ is supported as well $(r=0,261 ; P=* * *)$, as exploration has a positive impact on IC. Thereby, exploitation has a significantly influences on IC. These results are in line with prior literature that exploitation and exploration are fundamentally different logics that create tension because they compete for firms' scarce resources and strategic innovativeness focus (Nielsen 2010). Compared with exploitation, exploration focuses mainly on trying to create variety, to adapt and hence to exploit ever-decreasing windows of opportunity (Soosay and Hyland 2008). This behaviour is beneficial to the kind of product innovativeness that is characterized by radical change, risk and experimentation. It allows the creation of new methods, relationships, products or services (Augusto and Coelho 2009). Organizations engaging in explorative innovation pursue new knowledge and develop new products and services for emerging markets (Yalcinkaya et al. 2007), because it provides new insights into the design of new features and benefits of a given product that will contain new ideas (Cho and Pucik 2005). Exploration on innovation requires fundamental changes in the way an organization operates and represents a clear rupture with existing practices (Menguc and Auh 2006).

Competition intensity refers to the degree of competitive strengthen of a product/ market. One of the goals of developing innovative new products is to outperform competing firms, because an ability to innovate better and more rapidly implies an ability to respond to changing conditions faster (Calantone et al. 2002). However, intensified competition increases market uncertainty and unpredictability (Auh and Menguc 2005; Gupta et al. 2006). Thus, organizations might reduce investments in innovative ventures and revert to competences with more predictable outcomes to limit potential losses (Voss et al. 2008). Furthermore, in a highly competitive environment, it becomes more difficult for firms to gain access to the resources necessary to commercialize an innovation successfully (Lee et al. 2003). The role of exploration in creating differential advantages is supposed to be less evident in highly competitive markets, which requires prompt and concurrent responses to competing forces (Kim and Atuahene-Gima 2010). Furthermore, they pay greater attention to the organizational 


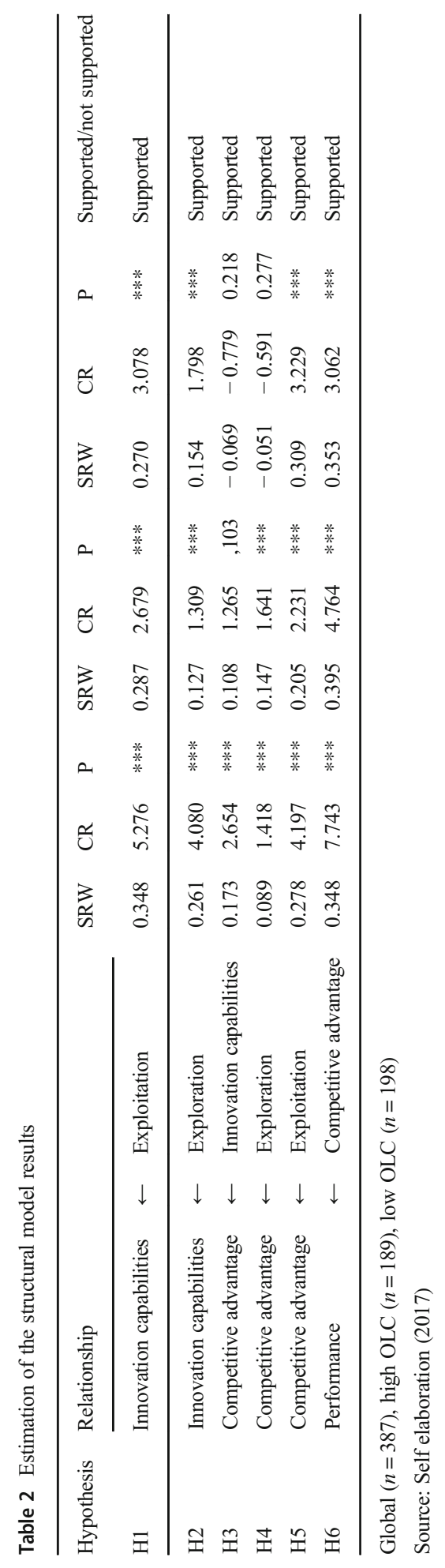


costs due to competitive pressure on prices and are more tempted to imitate competitors rather than exploring new opportunities (Day 1994; Kim and Atuahene-Gima 2010; Zhou 2006). Imitation enables firms to reduce the high cost of product innovation and thus improve their performance (Day 1994). As a result, companies will focus less on exploring new competences when they operate in a highly competitive environment.

However, on exploitation this impact is higher for high OLC than for low OLC ( $r=$ 0.287 against $r=0.270$ ), and on exploration we have an opposite result, higher for low OLC ( $r=0.127$, against $r=0.154)$. According to these results, there is a moderating relationship between OLC and exploitation and innovation. Thus, a learning culture might stimulate innovative behaviour among the members of an organization because it can lead them to accept innovation as a basic value of the organization and foster commitment to it (Hartmann 2006). Empirical research has also provided evidence of a significant relation between culture and innovation (Büschgens et al. 2013; Chang and Lee 2007; Lau and Ngo 2004; Lin et al. 2013). Past literature suggests that organizational learning might have a moderating effect on innovative performance (Alegre and Chiva 2013; Alegre and Chiva 2008; Jiménez-Jiménez and Sanz-Valle 2011). For Hsu and Fang (2009), organizational learning positively moderates the effects the innovation. Rothaermel and Deeds (2004) showed that organizational learning, which is created by external connection with workmates and partners, is effective for the improvement of new goods and innovation. Chang et al. (2010) tried to investigate and analyse the relationship between organizational learning and innovation. The results revealed that organizational learning capacities have a positive and meaningful relationship with organizational innovation. On the other words, organizational learning capacity is one of the fundamental, vital and facilitative factors for organizations that might lead to growth and innovation.

\section{Innovation Capability and Competitive Advantage}

IC has a significant impact on CA, consequently, supporting $\mathrm{H} 3(\underline{r}=0.173 ; P=* * *)$. This result is in line with prior investigation showing that IC is a special asset of a firm, as well as a positive and strong driver of performance. In fact, research in the last decade obtains empirical evidence of the direct relationship between IC, CA and, indirectly, performance (e.g. Adner and Helfat 2003; Kearney et al. 2014). Innovation is one of the key instruments to increase market share and to give the companies a CA having a positive impact on the performance of companies, producing a better position in the market and, therefore, resulting in competitive advantage and superior performance (Gunday et al. 2011). This result is significant only for the high OLC group ( $r=$ 0.108 against $r=-0.069$ ). According to prior investigation, the greater is the innovation achieved by an organization, the greater also is the learning and the change required by the system. The foundation of organizational knowledge, through which new knowledge is gained from existing knowledge (organizational learning), stimulates organizational innovation (Sanz-Valle et al. (2011)). High innovation requires a high and effective OLC (Ho 2011). OLC has a positive and significant influence on company's innovation (Chung et al. 2011; Tohidi and Mandegari 2012). Organizational learning "supports creativity, inspires new knowledge and ideas and increases the potential to understand and apply them, favours organizational intelligence and (with the culture) forms a background for orientation to organisational innovation" (García- 
Morales et al. 2007, p. 535). High levels of commitment to learning are attributed to greater innovative orientation and activity (Ussahawanitchakit 2008).

\section{Exploration and Exploitation and Competitive Advantage}

H4 is supported, as exploration has a positive impact on CA ( $r=0.089 ; P=* * *)$, and H5 is supported as well ( $r=0.278 ; P=* * *)$, as exploitation has a positive impact on CA. Thus, a firm's ability to compete in the long term may lie in its ability to integrate and build on its existing competences while at the same time developing fundamentally new ones (Lavie and Rosenkopf 2006). Simultaneous investments in the exploitation of existing product IC and the exploration of new ones may help create a CA (Soosay and Hyland 2008). Exploration and exploitation are generally used to describe activities that are essential for organizations in sustaining and ensuring their CA (Isobe et al. 2004).

According to the literature, organizational learning is the source of knowledge creation, and knowledge is a unique, inimitable and infinite resource (Koçoğlu et al. 2011). Organizational learning is emphasized as an important factor for boosting firm's CA. It is also considered a key factor for gaining a sustainable CA and enhanced firm performance (Martínez-Costa and Jiménez-Jiménez 2009). Previous investigation demonstrated that the effects of collaboration and team learning, continuous learning, inquiry and dialogue, empowerment of people, connection of organization to its environment and the support of leadership show that organizational learning practices and firm's financial performance are positively linked (Ellinger et al. 2002).

The moderating effect on exploitation is significant only for the high OLC group ( $r=0.147$ against $r=-0.051)$ and on exploration for both groups $(r=0.205$ against $r=$ $0.309)$. Results are in line with literature; that is, OLC is an important and essential source for organizations to gain a sustainable CA. According to Jerez-Gomez et al. (2005), this situation can also be a source of heterogeneity among organizations. Learning organizations have both more productive and adaptive structures when compared with conventional organizations, because of their commitment to learning, openness to new ideas, coping with complexity, continuously adjusting to new situations and challenges and self-renewal ability, considering the environmental demands (Jaw and Liu 2003; Jiménez-Jiménez and Sanz-Valle 2011; Kofman and Senge 1993). On the other hand, in this sense, firms today compete in dynamic markets, requiring them to explore new possibilities for adapting to the environmental changes that will occur soon while exploiting their abilities to meet current demands (Lavie and Rosenkopf 2006). Sustained innovation requires firms to explore new capabilities and exploit current capabilities (Wang and Hsu 2014), which rely on explorative and exploitative learning within the organizational learning domain (Tamayo-Torres et al. 2014).

According to March (1991), exploitation in the framework of organizational learning might be "refinement, choice, production, efficiency, selection, implementation, and execution" (p. 71). Gupta et al. (2006) classify exploitation and exploration in terms of the amount of learning. Exploitation is low risk (Vanhaverbeke et al. 2004) and thus presents only a low degree of uncertainty to the business. An extreme focus on exploitation can have negative results in the form of low levels of innovation leading to inertia (Schildt et al. 2005; Vanhaverbeke et al. 2004). Schildt et al. (2005) argue that an exploitative learning is short-term and meets the needs of a current market and 
customer requirements. After meeting these needs, a company can follow an explorative learning to extend its business by introducing new technology, novel ideas and new knowledge from the external environment (see Table 2).

\section{Competitive Advantage and Performance}

H6 is supported, as competitive advantage has a positive impact on CA $(r=0.348$; $P=* * *)$. This result is in line with the literature that supports the linkages between CA and firm performance (Wang and Lo 2003). The expected influence of mediating the variable is in line with previous studies (Rose et al. 2010) and supports the idea of an intrinsic relationship between these two variables, stronger among high OLC companies. The results are significant for both samples, although stronger for the high OLC group ( $r=0.395$ against $r=0.353$ ).

\section{Theoretical Implications}

This study investigated the following: (1) direct and indirect effect of exploitation and exploration on CA (2) moderating influence of OLC on exploration and exploitation capabilities and innovativeness and (3) mediating effect of IC on CA. It was found that most variables included in the model positively affected IC. The result of a host of conditions, including global competition and rapidly changing technological conditions, turns into an ever-present and increasingly rigorous challenge that firms are facing. The influence of this challenge to the organizational success is expected to increase in the decades ahead. The reality of constant and challenging environmental change potentially creates a need for organizations to alter their approach to developing and using CA as the pathway to superior performance. In our view, exploration and exploitation capabilities, mediated by innovation capability is an approach that can serve firms well in their efforts to rely on CA as the path to superior performance, both today and in the future. There may be an intersection between IC and CA, based on exploitation, and between IC and exploration for opportunities. These might be the building blocks around which future competitive advantages will be framed, and we believe that innovativeness captures a set of organizational actions with the capacity to strongly (and positively) contribute to a firm's efforts to outperform competitors.

Notwithstanding, the findings suggested some differences between exploitative and explorative innovations, but the similarities are more noticeable. Data shows that exploration innovations were scarcer than exploitation innovations but were generated by similar processes. This is different from the current theory, which specifies that low performance initially triggers local search and thus exploitation, but persistent problems cause expansion of search and potentially lead to exploration (Cyert and March 1963; Grinyer and McKiernan 1990; Katila and Ahuja 2002). Overall the findings show that organizational learning theory explains how organizations adjust the rates of explorative and exploitative innovations but it does better in predicting the overall level of each one than in predicting shifts between them. Finally, as expected, the findings provide evidence for the relation between firm innovation and performance. 


\section{Managerial Implications}

This paper makes several contributions to the theory of DCs and exploration and exploitation capabilities. It has been confirmed that dynamic capabilities have direct and indirect impact on firm CA.

Overall, the results of this study offer several guidelines to help companies develop new and successful products. In concrete terms, it sheds light on decisions regarding the relationship between exploitation and exploration and IC and the mediating impact on CA. The study builds on the four types of competences: exploitation (existing assets and capabilities) and exploration (the development of new capabilities), IC and the moderating role of OLC via commitment and their indirect and direct impact on CA. One of the main implications for managers is that both exploration and exploitation should be considered in parallel when developing new products. Thus, when exploration and exploitation meet simultaneously, SMEs are more competitive than those where only one of them occurs. This is notwithstanding the popular ambidexterity premise suggested by O'Reilly and Tushman (2004) that firms need to achieve a "balance" between the two to achieve superior performance. Ambidextrous firms can exploit existing competences as well as exploring new opportunities with equal dexterity (Gibson and Birkinshaw 2004 Lubatkin et al. 2006 Martin et al. 2017). As the two competences affect different aspects of new product advantage along different paths, the use of one type of competence at the exclusion of the other can diminish the effectiveness of the product development process and ultimately lead to a weak product performance, like the results reported by Kim and Atuahene-Gima (2010). Dynamic capability is one of an organization's core competences (Zahra et al. 2006), an important and direct source of sustainable competitive advantages (Lawton and Rajwani 2011; Sirmon et al. 2010; Chang and Kuo 2013). Teece (2007) claims that dynamic capabilities enable firms to gain competitive advantage in rapid (technological) changing markets. They also enable firms to adapt internal and external changes (Zahra and George 2002). Firms develop capabilities to deal with change. Therefore, although both exploration and exploitation as dynamic capabilities (Liu,et al., 2019; Vahlne and Jonsson 2017; Kuo et al. 2017 Fang, Wade, Delios, \& Beamish, 2013, Cao et al. 2018). Moreover, although exploration-exploitation yields a trade-off situation where exploration on innovation exhibits exploitation and performance may suffer, another stream of research claims that it is possible that firms have high levels of both exploration and exploitation on innovation (Gupta et al. 2006). If firms specialize in either exportation or exploitation via innovation, they can be successful indirectly on competitive advantage (Papadic \& Cerne, 2016).

Furthermore, there is a substantial consensus today that a key CA of organizations lies in their ability to learn and to be responsive to challenges from both internal and external business environments (Škerlavaj et al. 2007). Clearly, more attention must be paid to developing an OLC to improve organizational innovativeness. This can be achieved by cultivating an environment in which the employees can and should continually learn and share their knowledge. One practical implication of this thinking is that investing effort, time and money into initiatives aimed at developing a learning-oriented culture can bring about 
augmented innovativeness within firms SMEs. Portugal is no exception to this finding. Since the severe economic crisis in 1997, most of Portuguese organizations are more focused on the organizational innovation in terms of structural innovation and process innovation (Lim and Kah 2004). Thus, concentration on exploitation without exploration discourages the organization from pursuing learning and development (Auh and Menguc 2005). Firms must be aware of the limitation of their existing product innovation capabilities and should develop strategic flexibility in their resource allocation and coordination, such as flexibility to stimulate greater exploration of new technology and markets, which may help companies escape the competence trap (Zhou 2006).

However, the results of this study contain limitations, since they focus only on innovative capacity, not addressing other organizational capabilities, namely, technological capabilities, managerial capabilities, marketing capabilities and other.

\section{Conclusion}

The main goals of this research were to evaluate the impacts of DCs (exploitation and exploitation) on CA and performance, mediated by IC. The moderating role of OLC was tested to provide a specific context where these relationships could take place. The results are drawn from a cross-sectional investigation of 387 Portuguese companies, a transition economy that might provide a good field of research in the domain of dynamic capacities.

The mediating effects of IC were used to better understand the links and the way the effects from DCs are transmitted to performance and competitiveness. The character of DCs is rather cultural (Chen and Lee 2009), and hence their impacts on performance may be preferentially indirect. However, the results fill the gap to the theoretical and practical level by confirming the direct effects of the relationship between DCs and CA.

The results show, as well, that DCs (exploration and exploitation) have an indirect effect on performance and on competitiveness, via IC. These last capabilities act like an instrument from DCs to help companies to be more competitive and to have a better performance. Organizational learning culture exerts a strong and significant moderation influence both on competitiveness and performance and reinforces the effects of DCs on IC.

\section{Limitations}

This study has some methodological limitations affecting its potential contributions. As a cross-sectional study that captures one image in time, its ability to identify strict causality between variables is limited. Because capabilities and creativity-innovation co-evolve in a dynamic process, the ideal study might be longitudinal. As recommendations for future work, the model could be tested introducing variables like entrepreneurial and market orientation, both as mediators and moderators. Innovation and new product success are relevant outcomes which could also be tested. 


\section{Appendix}

Table 3 Measurement Scales

Exploitation source: Atuahene-Gima and Murray (2007)

Our aim was to search for information to refine common methods and ideas in solving problems in the project

Our aim was to search for ideas and information that we can implement well to ensure productivity rather than those ideas that could lead to implementation mistakes in the project and in the marketplace

We searched for the usual and generally proven methods and solutions to product development problems

We used information acquisition methods (e.g. survey of current customers and competitors) that helped us understand and update the firm's current project and market experiences

We used information acquisition methods (e.g. survey of current customers and competitors) that helped us understand and update the firm's current project and market experiences.

We emphasized the use of knowledge related to our existing project experience

\section{Exploration}

In information search, we focused on acquiring knowledge of project strategies that involved experimentation and high market risks

We preferred to collect information with no identifiable strategic market needs to ensure experimentation in the project.

Our aim was to acquire knowledge to develop a project that led us into new areas of learning such as new markets and technological areas

We collected novel information and ideas that went beyond our current market and technological experiences

Our aim was to collect new information that forced us to learn new things in the product development project

Innovation capability source: Merrilees et al. (2011) based Hooley et al. (2005)

Better at developing new ideas to help customers

More able to fast track new offerings to customers

Better able to manage processes to keep costs down

More able to package a total solution to solve customer problems

Competitive advantage source: Koufteros et al. (1997), Li et al. (2006), Thatte (2007)

We offer competitive prices

We are able to offer prices as low or lower than our competitors

We are able to compete based on quality

We offer products that are highly reliable

We offer products that are very durable

We offer high quality products to our customers

We deliver customer orders on time

We provide dependable delivery

We provide customized products

We alter our product offerings to meet client needs

We cater to customer needs for "new" features

We are first in the market in introducing new products

We have time-to-market lower than industry average

We have fast product development

Performance source: Morgan and Strong (2003)

Market share 
Table 3 (continued)

Customer satisfaction

Competitive position

Customer retention

Sales growth

Return on investment

Overall firm performance

Organizational learning capability-commitment source: Tohidi et al. (2012)

In this organization, managers frequently involve employees in important decisions

Policies are significantly influenced by the view of employees

People feel involved in main company decisions

Employee learning is considered more of an expense than an investment

Managers in this organization can accept criticism without becoming overly defensive

Senior managers in this organization resist change and are afraid of new ideas(r)

\section{References}

Adler, P. S., Goldoftas, B., \& Levine, D. I. (1999). Flexibility versus efficiency? A case study of model changeovers in the Toyota production system. Organization Science, 10(1), 43-68.

Adner, R., \& Helfat, C. E. (2003). Corporate effects and dynamic managerial capabilities. Strategic Management Journal, 24(10), 1011-1025.

Akgün, A. E., Keskin, H., Byrne, J. C., \& Aren, S. (2007). Emotional and learning capability and their impact on product innovativeness and firm performance. Technovation, 27(9), 501-513.

Akman, G., \& Yilmaz, C. (2008). Innovative capability, innovation strategy and market orientation: an empirical analysis in Turkish software industry. International Journal of Innovation Management, 12(01), 69-111.

Alegre, J., \& Chiva, R. (2008). Assessing the impact of organizational learning capability on product innovation performance: An empirical test. Technovation, 28(6), 315-326.

Alegre, J., \& Chiva, R. (2013). Linking entrepreneurial orientation and firm performance: the role of organizational learning capability and innovation performance. Journal of Small Business Management, 51(4), 491-507.

Ambrosini, V., \& Bowman, C. (2009). What are dynamic capabilities and are they a useful construct in strategic management? International Journal of Management Reviews, 11(1), 29-49.

Anderson, J. C., \& Gerbing, D. W. (1988). Structural equation modeling in practice: a review and recommended two-step approach. Psychological Bulletin, 103(3), 411-228.

Argyris, C., \& Schon, D. (1978). Organizational learning: a theory of action approach. Reading: Addision Wesley.

Atuahene-Gima, K. (2005). Resolving the capability-rigidity paradox in new product innovation. Journal of Marketing, 69(4), 61-83.

Atuahene-Gima, K., \& Murray, J. Y. (2007). Exploratory and exploitative learning in new product development: a social capital perspective on new technology ventures in China. Journal of International Marketing, 15(02), 1-29.

Augusto, M., \& Coelho, F. (2009). Market orientation and new-to-the-world products: exploring the moderating effects of innovativeness, competitive strength, and environmental forces. Industrial Marketing Management, 38(1), 94-108.

Auh, S., \& Menguc, B. (2005). Balancing exploration and exploitation: the moderating role of competitive intensity. Journal of Business Research, 58(12), 1652-1661.

Autant-Bernard, C., Fadairo, M., \& Massard, N. (2013). Knowledge diffusion and innovation policies within the European regions: challenges based on recent empirical evidence. Research Policy, 42(1), 196-210. 
Benner, M. J., \& Tushman, M. L. (2003). Exploitation, exploration, and process management: the productivity dilemma revisited. Academy of Management Review, 28(2), 238-256.

Burgelman, R. A. (1991). Intraorganizational ecology of strategy making and organizational adaptation: theory and field research. Organization Science, 2(3), 239-262.

Burgelman, R. A. (2002). Strategy as vector and the inertia of coevolutionary lock-in. Administrative Science Quarterly, 47(2), 325-357.

Büschgens, T., Bausch, A., \& Balkin, D. (2013). Organizational culture and innovation: a meta-analytic review. Journal of Product Innovation Management, 30(4), 1-19.

Calantone, R. J., Cavusgil, S. T., \& Zhao, Y. (2002). Learning orientation, firm innovation capability, and firm performance. Industrial Marketing Management, 31(6), 515-524.

Camisón, C., \& Villar-López, A. (2014). Organizational innovation as an enabler of technological innovation capabilities and firm performance. Journal of Business Research, 67(1), 2891-2902.

Cao, Q., Gedajlovic, E., \& Zhang, H. (2009). Unpacking organizational ambidexterity: dimensions, contingencies, and synergistic effects. Organization Science, 20(4), 781-796.

Cao, L., Navare, J., \& Jin, Z. (2018). Business model innovation: how the international retailers rebuild their core business logic in a new host country. International Business Review, 27(3), 543-562.

Cepeda, G., \& Vera, D. (2007). Dynamic capabilities and operational capabilities: a knowledge management perspective. Journal of Business Research, 60(5), 426-437.

Chang, C. C., \& Kuo, C. G. (2013). Exploring dynamic capabilities of executives for core strategy. African Journal of Business Management, 7(40), 4188-4198.

Chang, S. C., \& Lee, M. S. (2007). The effects of organizational culture and knowledge management mechanisms on organizational innovation: an empirical study in Taiwan. The Business Review, 7(1), 295-301.

Chang, T., Ebong, I., Bhadviya, B. B., Mazumder, P., Lu, J., \& S. H., W. (2010). Nanoscale memristor device as synapse in neuromorphic systems. Nano Letters, 10(4), 1297-1301.

Chen, H.-H., \& Lee, P.-Y. (2009). The driving drivers of dynamic competitive capabilities: a new perspective on competition. European Business Review, 21(1), 78-91.

Cheng, C., \& Huizingh, K. R. E. (2010). Open innovation to increase innovation performance: evidence from a large survey. In K. R. E. Huizingh, S. Conn, M. Torkelli, \& I. Bitran (Eds.), Proceedings of the XXI ISPIM International Conference, Bilbao, Spain, June 6-9.

Chipika, S., \& Wilson, G. (2006). Enabling technological learning among light engineering SMEs in Zimbabwe through networking. Technovation, 26(8), 969-979.

Cho, H. J., \& Pucik, V. (2005). Relationship between innovativeness, quality, growth, profitability, and market value. Strategic Management Journal, 26(6), 555-575.

Chung, H. F., Sue, T. C., \& Guan, L. C. (2011). Organizational learning capability and organizational innovation: the moderating role of knowledge inertia. African Journal of Business Management, 5(5), 1864-1870.

Collis, D. J. (1994). Research note: how valuable are organizational capabilities? Strategic Management Journal, 15(S1), 143-152.

Cyert, R. M., \& March, J. G. (1963). A behavioral theory of the firm. Englewood Cliffs, NJ, 2.

Day, G. S. (1994). The capabilities of market-driven organizations. The Journal of Marketing, 58(4), 37-52.

Eisenhardt, K. M., \& Martin, J. A. (2000). Dynamic capabilities: what are they? Strategic Management Journal, 21(10-11), 1105-1121.

Ellinger, A. D., Ellinger, A. E., Yang, B., \& Howton, S. W. (2002). The relationship between the learning organization concept and firms' financial performance: an empirical assessment. Human Resource Development Quarterly, 13(1), 5-22.

Fang, C. H., Chang, S. T., \& Chen, G. L. (2011). Organizational learning capability and organizational innovation: the moderating role of knowledge inertia. African Journal of Business Management, 5(5), 1864.

García-Morales, V. J., Ruiz-Moreno, A., \& Llorens-Montes, F. J. (2007). Effects of technology absorptive capacity and technology proactivity on organizational learning, innovation and performance: an empirical examination. Technology Analysis \& Strategic Management, 19(4), 527-558.

Gibson, C. B., \& Birkinshaw, J. (2004). The antecedents, consequences, and mediating role of organizational ambidexterity. Academy of Management Journal, 47(2), 209-226.

Gimenez, C., \& Ventura, E. (2003). Supply chain management as a competitive advantage in the Spanish grocery sector. The International Journal of Logistics Management, 14(1), 77-88.

Goh, S. C. (2003). Improving organizational learning capability: lessons from two case studies. The Learning Organization, 10(4), 216-227. 
Grinyer, P., \& McKiernan, P. (1990). Generating major change in stagnating companies. Strategic Management Journal, 11(SI), 131-146.

Gunday, G., Ulusoy, G., Kilic, K., \& Alpkan, L. (2011). Effects of innovation types on firm performance. International Journal of Production Economics, 133(2), 662-676.

Gupta, A. K., Smith, K. G., \& Shalley, C. E. (2006). The interplay between exploration and exploitation. Academy of Management Journal, 49(4), 693-706.

Haanaes, K. (2016). Why all businesses should embrace Sustainability Some top companies are leading the way. International Institute for Management Development, IMD, November.

Hahn, M. H., Lee, K. C., \& Lee, D. S. (2015). Network structure, organizational learning culture, and employee creativity in system integration companies: the mediating effects of exploitation and exploration. Computers in Human Behavior, 42(1), 167-175.

Hair Jr., J. F., Black, W. C., Babin, B. J., Anderson, R. E., \& Tatham, R. L. (2006). Multivariate data analysis (6th ed.). Upper Saddle River: Pearson-Prentice Hall.

Hartmann, A. (2006). The role of organizational culture in motivating innovative behaviour in construction firms. Construction Innovation, 6(3), 159-172.

He, Z. L., \& Wong, P. K. (2004). Exploration vs. exploitation: an empirical test of the ambidexterity hypothesis. Organization Science, 15(4), 481-494.

Helfat, C. E. (1997). Know-how and asset complementarity and dynamic capability accumulation: The case of R\&D. Strategic Management Journal, 18(5), 339-360.

Helfat, C. E. (2007). Stylized facts, empirical research and theory development in management. L 5(2), 185192.

Helfat, C. E., \& Peteraf, M. A. (2003). The dynamic resource-based view: capability lifecycles. Strategic Management Journal, 24(10), 997-1010.

Helfat, C. E., \& Raubitschek, R. S. (2000). Product sequencing: co-evolution of knowledge, capabilities and products. Strategic Management Journal, 21(10-11), 961-979.

Hernández-Espallardo, M., Sánchez-Pérez, M., \& Segovia-López, C. (2011). Exploitation-and explorationbased innovations: the role of knowledge in inter-firm relationships with distributors. Technovation, 31(5), 203-215.

Ho, L. A. (2011). Meditation, learning, organizational innovation and performance. Industrial Management and Data Systems, 111(1), 113-131.

Hooley, G., Greenley, G. E., Cadogan, W. J., \& Fahy, J. (2005). The performance impact of marketing resources. Journal of Business Research, 58(1), 18-27.

Hsu, Y. H., \& Fang, W. (2009). Intellectual capital and new product development performance: the mediating role of organizational learning capability. Technological Forecasting and Social Change, 76(5), 664-677.

Hult, G. T. M., \& Ketchen Jr., D. J. (2001). Does market orientation matter?: A test of the relationship between positional advantage and performance. Strategic Management Journal, 22(9), 899-906.

Hult, G. T. M., Hurley, R. F., \& Knight, G. A. (2004). Innovativeness: its antecedents and impact on business performance. Industrial Marketing Management, 33(5), 429-438.

Hurley, R. F., \& Hult, G. T. M. (1998). Innovation, market orientation, and organizational learning: an integration and empirical examination. The Journal of Marketing, 62(3), 42-54.

Isobe, T., Makino, S., \& Montgomery, D. B. (2004). Exploitation, exploration, and firm performance: the case of small manufacturing firms in Japan. Working Paper, Research Collection Lee Kong Chian School Of Business.

Jansen, J. J., Van Den Bosch, F. A., \& Volberda, H. W. (2006). Exploratory innovation, exploitative innovation, and performance: effects of organizational antecedents and environmental moderators. Management Science, 52(11), 1661-1674.

Jaw, B. S., \& Liu, W. (2003). Promoting organizational learning and self-renewal in Taiwanese companies: the role of HRM. Human Resource Management, 42(3), 223-241.

Jerez-Gomez, P., Céspedes-Lorente, J., \& Valle-Cabrera, R. (2005). Organizational learning capability: a proposal of measurement. Journal of Business Research, 58(6), 715-725.

Jiménez-Jiménez, D., \& Sanz-Valle, R. (2011). Innovation, organizational learning, and performance. Journal of Business Research, 64(4), 408-417.

Kafetzopoulos, D., \& Psomas, E. (2015). The impact of innovation capability on the performance of manufacturing companies: the Greek case. Journal of Manufacturing Technology Management, 26(1), 104-130.

Katila, R., \& Ahuja, G. (2002). Something old, something new: a longitudinal study of search behavior and new product introduction. Academy of Management Journal, 45(6), 1183-1194.

Kearney, A., Harrington, D., \& Kelliher, F. (2014). Exploiting managerial capability for innovation in a microfirm context. European Journal of Training and Development, 38(1-2), 95-117. 
Kim, N., \& Atuahene-Gima, K. (2010). Using exploratory and exploitative market learning for new product development. Journal of Product Innovation Management, 27(4), 519-536.

Koçoğlu, İ., İmamoğlu, S. Z., İnce, H., \& Keskin, H. (2011). The effect of supply chain integration on information sharing: enhancing the supply chain performance. Procedia-Social and Behavioral Sciences, 24(1), 1630-1649.

Kofman, F., \& Senge, P. (1993). Communities of commitment: the heart of learning organizations in organizational dynamics. Autumn, 22(2), 5-23.

Kogut, B., \& Zander, P. U. (1992). Knowledge of the firm, combinative capabilities, and the replication of technology. Organization Science, 3(3), 383-397.

Koufteros XA, Vonderembse MA and Doll WJ (1997). Competitive capabilities: measurement and relationships. proceedings decision science institute: Atlanta, GA,9 (2), 256-282.

Kuo, S. Y., Lin, P. C., \& Lu, C. S. (2017). The effects of dynamic capabilities, service capabilities, competitive advantage, and organizational performance in container shipping. Transportation Research Part A: Policy and Practice, 95(1), 356-371.

Kyrgidou, L. P., \& Petridou, E. (2011). The effect of competence exploration and competence exploitation on strategic entrepreneurship. Technology Analysis \& Strategic Management, 23(6), 697-713.

Lau, C. M., \& Ngo, H. Y. (2004). The HR system, organizational culture, and product innovation. International Business Review, 13(6), 685-703.

Lavie, D., \& Rosenkopf, L. (2006). Balancing exploration and exploitation in alliance formation. Academy of Management Journal, 49(4), 797-818.

Lavie, D., Stettner, U., \& Tushman, M. L. (2010). Exploration and exploitation within and across organizations. Academy of Management Annals, 4(1), 109-155.

Lawton, T., \& Rajwani, T. (2011). Designing lobbying capabilities: managerial choices in unpredictable environments. European Business Review, 23(2), 167-189.

Lee, J., Lee, J. S., \& Lee, H. (2003). Exploration and explotation in the presence of network externalities. Management Science, 49(4), 553-570.

Lee, S. M., Lim, S. B., \& Pathak, R. D. (2011). Culture and entrepreneurial orientation: a multicountry study. International Entrepreneurship and Management Journal, 7(1), 1-15.

Leonard-Barton, D. (1992). The factory as a learning laboratory.

Levinthal, D. A., \& March, J. G. (1993). The myopia of learning. Strategic Management Journal, 14(S2), 95112.

Li, D. Y., \& Liu, J. (2014). Dynamic capabilities, environmental dynamism, and competitive advantage: evidence from China. Journal of Business Research, 67(1), 2793-2799.

Li, S., Ragu-Nathan, B., Ragu-Nathan, T. S., \& Rao, S. S. (2006). The impact of supply chain management practices on competitive advantage and organizational performance. Omega, 34(1), 107-124.

Li, C. R., Lin, C. J., \& Chu, C. P. (2008). The nature of market orientation and the ambidexterity of innovations. Management Decision, 46(7), 1002-1026.

Li, J., Liu, M., \& Liu, X. (2016). Why do employees resist knowledge management systems? An empirical study from the status quo bias and inertia perspectives. Computers in Human Behavior, 65(4), 189-200.

Lichtenthaler, U. (2009). Absorptive capacity, environmental turbulence, and the complementarity of organizational learning processes. Academy of Management Journal, 52(4), 822-846.

Lim, C. H., \& Kah, J. S. (2004). Teams in Korea. Seoul: Samsung Economic Research Institute.

Lin, R. J., Tan, K. H., \& Geng, Y. (2013). Market demand, green product innovation, and firm performance: evidence from Vietnam motorcycle industry. Journal of Cleaner Production, 40(1), 101-107.

Lisboa, A., Skarmeas, D., \& Lages, C. (2011). Innovative capabilities: their drivers and effects on current and future performance. Journal of Business Research, 64(11), 1157-1161.

Lubatkin, M. H., Simsek, Z., Ling, Y., \& Veiga, J. F. (2006). Ambidexterity and performance in small-to medium-sized firms: The pivotal role of top management team behavioral integration. Journal of Management, 32(5), 646-672.

Ma, H. (2000). Competitive advantage and firm performance. Competitiveness Review, 10(2), 15-32.

March, J. (1991). Exploration and exploitation in organizational learning. Organization Science, 2(1), 71-87.

Marín-Idárraga, D. A., Hurtado González, J. M., \& Cabello Medina, C. (2016). The antecedents of exploitation-exploration and their relationship with innovation: a study of managers' cognitive maps. Creativity and Innovation Management, 25(1), 18-37.

Martin, S. L., Javalgi, R. G., \& Cavusgil, E. (2017). Marketing capabilities, positional advantage, and performance of born global firms: Contingent effect of ambidextrous innovation. International Business Review, 26(3), 527-543. 
Martín-de Castro, G., Delgado-Verde, M., Navas-López, J. E., \& Cruz-González, J. (2013). The moderating role of innovation culture in the relationship between knowledge assets and product innovation. Technological Forecasting and Social Change, 80(2), 351-363.

Martínez-Costa, M., \& Jiménez-Jiménez, D. (2009). The effectiveness of TQM: the key role of organizational learning in small businesses. International Small Business Journal, 27(1), 98-125.

McAdam, R., \& Keogh, W. (2004). Transitioning towards creativity and innovation measurement in SMEs. Creativity and Innovation Management, 13(2), 126-139.

Menguc, B., \& Auh, S. (2006). Creating a firm-level dynamic capability through capitalizing on market orientation and innovativeness. Journal of the Academy of Marketing Science, 34(1), 63-73.

Merrilees, B., Rundle-Thiele, S., \& Lye, A. (2011). Marketing capabilities: antecedents and implications for B2B SME performance. Industrial Marketing Management, 40(3), 368-375.

Mishra, A. A., \& Shah, R. (2009). In union lies strength: collaborative competence in new product development and its performance effects. Journal of Operations Management, 27(4), 324-338.

Morgan, R. E., \& Strong, C. A. (2003). Business performance and dimensions of strategic orientation. Journal of Business Research, 56(3), 163-176.

Narver, J. C., \& Slater, S. F. (1990). The effect of a market orientation on business profitability. Journal of Marketing, 54(4), 20-35.

Nelson, R. R., \& Winter, S. G. (1982). The Schumpeterian tradeoff revisited. The American Economic Review, 72(1), 114-132.

Nielsen, S. (2010). Top management team diversity: a review of theories and methodologies. International Journal of Management Reviews, 12(3), 301-316.

O'Cass, A., \& Sok, P. (2012). Examining the role of within functional area resource-capability complementarity in achieving customer and product-based performance outcomes. Journal of Strategic Marketing, 20(4), 345-363.

Ohr, R. C., \& Mattes, F. (2013). Balancing innovation via organizational ambidexterity. Working Paper.

O'Reilly 3rd, C. A., \& Tushman, M. L. (2004). The ambidextrous organization. Harvard Business Review, $82(4), 74$.

O'Reilly, C., \& Tushman, M. (2008). Ambidexterity as a dynamic capability: resolving the innovator's dilemma. Research in Organizational Behavior, 28(1), 185-206.

Peteraf, M. A., \& Barney, J. B. (2003). Unraveling the resource-based tangle. Managerial and Decision Economics, 24(4), 309-323.

Podsakoff, P. M., \& MacKenzie, S. B. (2003). An examination of the psychometric properties and homological validity of some revised and reduced substitutes for leadership scales. Journal of Applied Psychology, 79(5), 702-713.

Podsakoff, P. M., \& Organ, D. W. (1986). Self-reports in organizational research: problems and prospects. Journal of Management, 12(1), 69-82.

Porter, M. E. (1990). The competitive advantage of nations. Harvard Business Review, 68(2), 73-93.

Preda, G. (2014). Organizational ambidexterity and competitive advantage: toward a research model. Management \& Marketing Journal, 15(1), 67-74.

Raisch, S., \& Birkinshaw, J. (2008). Organizational ambidexterity: antecedents, outcomes, and moderators. Journal of Management, 34(3), 375-409.

Raisch, S., Birkinshaw, J., Probst, G., \& Tushman, M. L. (2009). Organizational ambidexterity: balancing exploitation and exploration for sustained performance. Organization Science, 20(4), 685-695.

Robey, D., Ross, J. W., \& Boudreau, M. C. (2002). Learning to implement enterprise systems: an exploratory study of the dialectics of change. Journal of Management Information Systems, 19(1), 17-46.

Rose, R. C., Abdullah, H., \& Ismad, A. I. (2010). A review on the relationship between organizational resources, competitive advantage and performance. Journal of International Social Research, 15(2), 157173.

Rothaermel, F. T., \& Deeds, D. L. (2004). Exploration and exploitation alliances in biotechnology: a system of new product development. Strategic Management Journal, 25(3), 201-221.

Sanz-Valle, R., Naranjo-Valencia, J. C., Jimenez-Jimenez, D., \& Perez-Caballero, L. (2011). Linking organizational learning with technical innovation and organizational culture. Journal of Knowledge Management, 15(6), 997-1015.

Saunila, M., Pekkola, S., \& Ukko, J. (2014). The relationship between innovation capability and performance: the moderating effect of measurement. International Journal of Productivity and Performance Management, 63(2), 234-249.

Schendel, D. (1996). Evolutionary perspectives on strategy. Strategic Management Journal, 17(S1), 1-4.

Schildt, H. A., Maula, M. V., \& Keil, T. (2005). Explorative and exploitative learning from external corporate ventures. Entrepreneurship Theory and Practice, 29(4), 493-515. 
Shiu, E., Pervan, S., Bove, L., \& Beatty, S. (2011). Reflections on discriminant validity: reexamining the Bove et al. (2009) findings. Journal of Business Research, 64(5), 497-500.

Simsek, Z., Heavey, C., Veiga, J. F., \& Souder, D. (2009). A typology for aligning organizational ambidexterity's conceptualizations, antecedents, and outcomes. Journal of Management Studies, 46(5), 864-894.

Sinkula, J. M., Baker, W. E., \& Noordewier, T. (1997). A framework for market-based organizational learning: linking values, knowledge, and behavior. Journal of the Academy of Marketing Science, 25(4), 305-318.

Sirén, C. A., Kohtamäki, M., \& Kuckertz, A. (2012). Exploration and exploitation strategies, profit performance, and the mediating role of strategic learning: escaping the exploitation trap. Strategic Entrepreneurship Journal, 6(1), 18-41.

Sirmon, D. G., Hitt, M. A., Arregle, J. L., \& Campbell, J. T. (2010). The dynamic interplay of capability strengths and weaknesses: investigating the bases of temporary competitive advantage. Strategic Management Journal, 31, 1386-1409.

Škerlavaj, M., Štemberger, M. I., \& Dimovski, V. (2007). Organizational learning culture - the missing link between business process change and organizational performance. International Journal of Production Economics, 106(2), 346-367.

Soosay, C., \& Hyland, P. (2008). Exploration and exploitation: the interplay between knowledge and continuous innovation. International Journal of Technology Management, 42(1-2), 20-35.

Stata, R., \& Almond, P. (1989). Organizational learning: the key to management innovation. The training and development sourcebook, 15(2), 31-42.

Suharyono, P., Imam, S., \& Zainul, A. (2014). The effect of market orientation and entrepreneurial orientation toward learning orientation, innovation, competitive advantages and marketing performance. European Journal of Business and Management, 6(21), 69-80.

Suliyanto, S. (2011). Effect of entrepreneurship orientation and marketing-based reward system towards marketing performance. International Journal of Business and Social Science, 2(6), 168-174.

Tamayo-Torres, J., Gutierrez-Gutierrez, L., \& Ruiz-Moreno, A. (2014). The relationship between exploration and exploitation strategies, manufacturing flexibility and organizational learning: an empirical comparison between non-ISO and ISO certified firms. European Journal of Operational Research, 232(1), 72-86.

Teece, D. J. (2007). Explicating dynamic capabilities: the nature and microfoundations of (sustainable) enterprise performance. Strategic Management Journal, 28(13), 1319-1350.

Teece, D., \& Pisano, G. (1994). The dynamic capabilities of firms: an introduction. Industrial and Corporate Change, 3(3), 537-556.

Teece, D., Pisano, G., \& Shuen, A. (1997). Dynamics capabilities and strategic management. Strategic Management Journal, 18(7), 509-533.

Thatte, A.A. (2007) Competitive advantage of a firm through supply chain responsiveness and supply chain management practices, Published PhD Dissertation, University of Toledo.

Thatte, U. M., Puri, K. S., Suresh, K. R., \& Gogtay, N. J. (2009). Declaration of Helsinki, 2008: implications for stakeholders in research. Journal of Postgraduate Medicine, 55(2), 131.

Tidd, J. (2006). A review of innovation models. Imperial College London, 16.

Tohidi, H., \& Mandegari, M. (2012). Assessing the impact of organizational learning capability on firm innovation. African Journal of Business Management, 6(12), 4522-4538.

Tohidi, H., Seyedaliakbar, S. M., \& Mandegari, M. (2012). Organizational learning measurement and the effect on firm innovation. Journal of Enterprise Information Management, 25(3), 219-245.

Tsai, W. (2002). Social structure of "coopetition" within a multiunit organization: coordination, competition, and intraorganizational knowledge sharing. Organization Science, 13(2), 179-190.

Tushman, M. L., \& O'Reilly III, C. A. (1996). Ambidextrous organizations: managing evolutionary and revolutionary change. California Management Review, 38(4), 8-29.

Ussahawanitchakit, P. (2008). Organizational learning capability, organizational commitment, and organizational effectiveness: an empirical study of Thai accounting firms. Journal of International Business Strategy, 8(3), 1-12.

Vahlne, J. E., \& Jonsson, A. (2017). Ambidexterity as a dynamic capability in the globalization of the multinational business enterprise (MBE): Case studies of AB Volvo and IKEA. International Business Review, 26(1), 57-70.

Vanhaverbeke, W., Beerkens, B., Gilsing, V., \& Duysters, G. (2004). Explorative and exploitative learning strategies in technology-based alliance networks. Academy of Management Best Conference Paper, J1-J6 working paper.

Verona, G., \& Ravasi, D. (2003). Unbundling dynamic capabilities: an exploratory study of continuous product innovation. Industrial and Corporate Change, 12(3), 577-606. 
Voss, G. B., Sirdeshmukh, D., \& Voss, Z. G. (2008). The effects of slack resources and environmental threat on product exploration and exploitation. Academy of Management Journal, 51(1), 147-164.

Wang, C. H., \& Hsu, L. C. (2014). Building exploration and exploitation in the high-tech industry: the role of relationship learning. Technological Forecasting and Social Change, 81, 331-340.

Wang, Y., \& Lo, H. P. (2003). Customer-focused performance and the dynamic model for competence building and leveraging a resource-based view. Journal of Management Development, 22(1), 483-526.

Wiklund, J., \& Shepherd, D. (2003). Knowledge-based resources, entrepreneurial orientation, and the performance of small and medium-sized businesses. Strategic Management Journal, 24(13), 1307-1314.

Williamson, O. E. (1975). Markets and hierarchies: analysis and antitrust implications: a study in the economics of internal organization, 86 (343) 619-621.

Winter, S. G. (2003). Understanding dynamic capabilities. Strategic Management Journal, 24(10), 991-995.

Xie, X., Fang, L., Zeng, S., \& Huo, J. (2016). How does knowledge inertia affect firms product innovation? Journal of Business Research, 69(5), 1615-1620.

Yalcinkaya, G., Calantone, R. J., \& Griffith, D. A. (2007). An examination of exploration and exploitation capabilities: implications for product innovation and market performance. Journal of International Marketing, 15(4), 63-93.

Yang, C.-H., \& Huang, Y.-J. (2009). Do intellectual property rights matter to Taiwan's exports? A dynamic panel approach. Pacific Economic, 14(4), 555-578.

Zahra, S. A., \& George, G. (2002). The net-enabled business innovation cycle and the evolution of dynamic capabilities. Information Systems Research, 13(2), 147-150.

Zahra, S. A., Sapienza, H. J., \& Davidsson, P. (2006). Entrepreneurship and dynamic capabilities: a review, model and research agenda. Journal of Management Studies, 43(4), 917-955.

Zemplinerová, A. (2010). Inovační aktivita firem a konkurence. Politická ekonomie, 58(6), 747-760.

Zhou, K. Z. (2006). Innovation, imitation, and new product performance: the case of China. Industrial Marketing Management, 35(3), 394-402.

Zollo, M., \& Winter, S. G. (2002). Deliberate learning and the evolution of dynamic capabilities. Organization Science, 13(3), 339-351.

Publisher's Note Springer Nature remains neutral with regard to jurisdictional claims in published maps and institutional affiliations. 